\title{
Research on innovation system construction of physical education teaching mode in colleges and universities from the perspective of sunshine sports
}

\author{
Lihua Wang ${ }^{1, a}$, Huiming Li ${ }^{2, b}$ Lichun Yang ${ }^{3, c}$ \\ ${ }^{1}$ Colege of physical education, Yunnan agricultural university, Kunming 650201, China \\ ${ }^{2}$ Colege of physical education, Yunnan agricultural university, Kunming 650201, China \\ ${ }^{3}$ Ministry of sports,sun yat-sen university, Guangzhou 510275, China \\ aemail lihuaww98@163.con, bemail lihuiming735@163.com , cemail yangchun19@126.com
}

Keywords: new curriculum reform; sunshine sports; innovation

\begin{abstract}
The concept of the new curriculum reform deepening, disadvantages of physical education in Colleges and universities have become more and more obvious, especially the influence of teaching mode is not reasonable, the university sports teaching presents the present situation of high input and low teaching achievements of teaching. From the perspective of sunshine sports, teaching effectiveness of college physical education teaching mode can highlight the existing sports teaching activities in Colleges and universities, to carry out timely adjustment and innovation have become an inevitable, relying on innovative teaching mode to drive the overall teaching innovation is also a good choice. This article will analyze the problems existing in Physical Education in Colleges and universities from the perspective of sunshine sports, and put forward reasonable suggestions on how to construct the innovative system of physical education teaching mode in Colleges and universities.
\end{abstract}

\section{Introduction}

College is the main position of talent training, influence the development of demand for comprehensive and balanced development of talents in higher education, science and culture should not only focus on the teaching of knowledge, but also through sports and art education impact on students' growth and development. Through the research, we can find that the existing teaching model has been unable to meet the actual needs of physical education in Colleges and universities, and many colleges and universities are very slow in the process of physical education teaching innovation and reform. From the perspective of sunshine sports, although some colleges and universities have adjusted their physical education, their teaching mode has not changed substantially. Therefore, how to build an innovative system of somatic education in Colleges and universities and to promote the sound development of physical education in Colleges and universities is also a practical problem worth thinking about[1].

\section{Overview of physical education in Colleges and Universities}

College physical education is an important part of higher education system, which not only bear the task of schooling basic knowledge dissemination of sports, more through sports teaching better to enhance students' physical quality, so as to promote the balanced development of students. As the organic composition in the system of higher education, college physical education is also facing great pressure in the reform of education and teaching under the new curriculum reform, especially the establishment of national physical education programs more sunlight, resulting in efficient sports teaching has exposed a lot of problems. The university sports teaching in some areas while a lot of effort in teaching innovation, innovation and innovation in teaching content but mostly stay in the 
form the level of innovation, ignoring the innovative teaching mode of College Physical Education for a direct result of its series of teaching innovation can not meet the expected teaching goal of innovation. In China, sunshine sports education activities have been conducted among hundreds of millions of students in the country. It is the key to improve the effectiveness of physical teaching activities in the light of sunshine sports education and actively carry on the innovation of physical education teaching mode in colleges and universities[2].

\section{The significance of teaching mode innovation in college physical education from the perspective of sunshine sports}

\section{To improve the effectiveness of physical education}

From the perspective of sunshine sports, the innovation of PE teaching mode in universities is beneficial to the promotion of the effectiveness of the entire teaching. Education and teaching activities are required to consume a certain amount of education and teaching resources. At present, the overall teaching effectiveness in college physical education is low, and the teaching quality and level of physical education in Colleges and universities are uneven. From the perspective of sunshine sports, sports teaching mode in colleges and universities better innovation, carry out education and teaching activities can be more suitable for students' demand for education, has significantly improved the university sports teaching effectiveness and teaching quality can. In addition, after the PE teaching model is well innovated, it can provide better help for the innovation of the teaching content and the innovation of the teaching form. In this context, PE teachers in colleges and universities can have a better grasp of the overall teaching, and a series of excellent innovative teaching methods applied in college physical education, but also conducive to the effectiveness of physical education in Colleges and universities.

\section{It is beneficial to achieve the goal of new curriculum reform}

From the perspective of sunshine sports, the construction of an innovative system of physical education teaching mode in colleges and universities is also beneficial to the achievement of the teaching objectives of the new curriculum reform. Under the background of new curriculum reform of PE Teaching in Colleges and universities in the education teaching goal and goal of talent training is more diverse and scientific, but the influence of the traditional teaching mode and teaching method, impetus university sports teaching in the classroom reform in the new curriculum reform is obviously insufficient, the whole process is extremely slow. With the help of constructing innovation system of college physical education, college physical education exists in the series of problems can be found in time, these obstacles of new curriculum reform process factors are solve, college sports teaching in the new curriculum objectives can be more smoothly. In addition, from the perspective of the sunshine sports college sports teaching mode innovation system construction process, teachers can accumulate more experience under the innovation of PE teaching, it can also provide great help for the innovation and development of PE Teaching in Colleges and universities, and agreed to further promote the new courses of college sports teaching reform goal[3].

\section{The problems existing in the innovation of college physical education teaching mode}

\section{The traditional teaching philosophy is deeply rooted}

At present, college physical education teaching the traditional teaching idea is ingrained, the influence of traditional teaching concept of college sports teaching is very obvious, more and more college PE teachers in the traditional teaching concept to teach mode innovation system construction breakthrough. Although university sports teaching and regular teaching is different, but the influence is too traditional and mechanical teaching philosophy, the continuing loss of university sports teaching activity, the characteristics of sports teaching itself more and more desalination. In many universities, the status of physical education teaching in the whole teaching system in college physical education is more awkward, the edge feature, the teaching activities and teaching innovation cannot get better support of colleges and universities. In addition, the innovation of many colleges 
and universities physical education teachers in the teaching of the attempt to influence of traditional teaching concept, the innovation of teaching achievements will also be affected, the traditional teaching concept and Sunshine Physical Education between incompatible, but also the traditional education idea to provide help for the construction from the perspective of sunshine sports college sports teaching mode innovation system[4].

\section{The construction of sports teaching infrastructure lags behind}

In recent years, despite the fact that the state has invested more funds for promoting the development of higher education, but many universities in the use of special funds for education did not make good planning, a considerable part of the infrastructure construction, physical education lags behind. Physical education should not only explain and impart the general knowledge of physical education students, but also make the connection between physical education and physical education very closely. In many colleges and universities, the total amount of sports teaching infrastructure is small, the number of sports activities is insufficient, and some sports teaching activities cannot be effectively carried out in the simple sports teaching facilities. Due to the lag of infrastructure construction of sports teaching, sports teaching many innovative attempts to implement, and physical education infrastructure support is insufficient, conventional physical education itself interesting and diversity will be a serious shortage, which is obviously not conducive to carry out routine teaching activities of college physical education. Sunshine sports teaching idea are a kind of educational philosophy that emphasizes the teaching of physical education in sports. The construction of physical education teaching infrastructure in Colleges and universities lags behind, and there is no way to construct the innovation model of somatic education in Colleges and universities[5].

\section{There is less contact between teachers and students in Physical Education}

Under the impact of the existing mode of physical education in Colleges and universities, there is little connection between teachers and students. Many teachers are not in a position to interact well with students in PE teaching because of the complicated composition of their faculties. It is because of teachers and students in PE teaching contact less, innovation system of PE Teaching in Colleges and universities to construct the emergence of the "Big word seldom accompany great deed." situation, some university teachers in the teaching mode innovation system construction is very weak". From the selection and application of the method of teaching, college PE teachers in physical education are not fully involved in the teaching practice, it is usually in the arrangement of certain teaching tasks and lets students own sports activities and influence of this teaching method, a lot of students learning to sports professional knowledge, sports teaching the teaching of color is also very weak. The teachers and students in PE teaching contact less, many sports teachers are unable to sports teaching present situation, existing problems in the teaching of physical education and physical education to grasp the actual needs of students, it is also very easy to cause the sports teaching mode innovation system of college physical education teachers construction and practice from each other[6].

\section{The target consciousness of the whole teaching is weak}

University sports teaching has the specific target consciousness of lack of overall teaching, many colleges and universities for physical education teaching the importance of the teaching activities in university physical education is difficult to obtain scientific planning. From the perspective of sunshine sports, somatic education in Colleges and universities should make clear the objectives of education and teaching, and the deepening of the new curriculum reform requires more strong direction of physical education in Colleges and universities. However, in the actual teaching, many colleges and universities physical education teachers are not good, planning for the overall teaching, smooth teaching of physical education have become the basic option of its sports teaching activities. Because of the weak goal orientation in the whole teaching of physical education, various teachers will gradually lose their enthusiasm for the construction of sports teaching and innovation system. Institutions of higher learning do not attach importance to the establishment and achievement of sports teaching objectives, and also directly lead to the lack of a suitable internal environment for sports teaching in Colleges and universities to support them. It is no exaggeration to say that under the 
weakness of the overall teaching goal of the college physical education, the goal of the innovation system of the PE teaching model in Colleges and universities cannot be reached.

\section{The construction of innovation system of physical education teaching mode from the perspective of sunshine sports}

\section{Change the teaching idea in time;}

From the perspective of sunshine sports, the construction of the innovation system of somatic education teaching mode in Colleges and universities should be carried out in a timely manner. The traditional teaching concept has been unable to meet the needs of sports teaching reform in Colleges and universities, combined with the sunshine physical education essence, and will be more methodical and advanced teaching theory applied in teaching practice is very necessary. Special training in Colleges and universities needs to carry out of college physical education teachers, in the sunshine sports education related knowledge as a basis for training content, constantly enhance the awareness on the importance of sunshine sports and university sports teaching staff. In the physical education teachers in Colleges and universities of sunshine sports education has full knowledge and understanding on the basis of college physical education teachers should encourage innovative attempts, and timely establish a more inventive concept of education and teaching auxiliary routine teaching activities. The influence of educational teaching concept on teaching activities is very far-reaching and obvious. In the construction of teaching mode innovation system, the relevant work of enlightening concept adjustment should be placed in the first place[7].

\section{Increase the infrastructure construction of Physical Education}

The construction of the innovation system of somatic education teaching mode in Colleges and universities should also strengthen the construction of sports teaching infrastructure, and constantly enrich the types of sports teaching infrastructure, and enhance the support role of sports teaching infrastructure for physical education. Specifically, the internal needs of colleges and universities should be combined with the actual construction of sports infrastructure, as well as innovative needs of sports teaching model from the perspective of sunshine sports, to carry out specific physical education infrastructure construction attempts. In protection of sports teaching infrastructure construction funds support, for sports teaching infrastructure construction work better co-ordination. The innovation of the teaching mode of sports higher degree of dependence on the sports teaching facilities, physical education teachers should increase the utilization degree of sports venues and sports infrastructure in sports teaching, which makes the related infrastructure construction of PE teaching can try teaching mode for the construction of innovation system of sports have a direct role. In the actual teaching, the physical education teacher should train the student to use the sports infrastructure to carry on the movement of the good custom, thus causes the sunlight sports angle of view sports teaching in the university to be more rich and diverse.

\section{Diversified sports teaching methods}

From the perspective of sunshine sports, college sports teaching mode innovation system construction is closely related with better teaching methods, teaching method of single has proved unable to meet the actual needs of teaching, sports teaching methods, and the application of the teaching method innovation of strong color in practical teaching is very necessary. College PE teachers should first have the application of teaching method to increase the degree of interactive teaching into the teaching, for example, in the teaching of physical education, physical education teachers can be grouped by grouping teaching, students and students to participate in sports, not only can enhance the relationship between teachers and students, to help teachers discover the existing problems in the teaching of physical education. At this stage, such as situational teaching methods, game teaching methods, such as physical education teaching innovation methods are more, college sports teachers in sports teaching methods diversification choice of space are relatively more. But it should be pointed out that the innovation of physical education teaching methods should follow the principle of teaching practice and avoid excessive teaching methods innovation, which will have a negative impact on routine teaching activities. 


\section{Make clear the basic direction and phased goal of Physical Education Teaching}

The university sports teaching need to clear the basic direction of teaching and teaching objectives, construct innovation system of PE Teaching in Colleges and universities need to become the overall goal of College Physical Education from the perspective of sunshine education, University will increase the charm of the sunshine education as the basic direction of education. It is therefore suggested that the PE teachers in Colleges and universities should plan and segment the sports teaching activities better, and establish the teaching objectives that should be reached in each teaching stage. On the basis of that, it is helpful for College PE teachers to better understand their own teaching models and methods. In the overall teaching stage and to reach goals, constructing innovation system of college physical education teaching difficulty and pressure will continue to decrease, which can make the physical education teachers in Colleges and universities in the teaching mode innovation system construction to have the better performance[8].

\section{Conclusion}

Higher education is a higher level of education, the students' growth and development have great impact, the university sports teaching well, more able to reach the physical and mental health of students in comprehensive development goals to help. From the perspective of sunshine sports series, exist in the physical education teaching in Colleges and universities problems should be pay attention to application of colleges and universities, but also with the sunshine sports education purpose, teaching for college sports to solve the series of problems. The construction of the innovation system of physical education teaching mode in universities should be well planned, and the internal system of colleges and universities should adhere to the construction of the innovation system of PE teaching mode as a normalization work.

\section{References}

[1] Hofmann A R. Between Traditions and New Challenges: 25 Years of the International Society of the History of Physical Education and Sport (ISHPES)[J]. The International Journal of the History of Sport, 2014, 31(9):970-975.

[2]Carlgren L, Elmquist M, Rauth I. Design Thinking: Exploring Values and Effects from an Innovation Capability Perspective[J]. The Design Journal, 2014, 17(3):403-423.

[3]Pan X, Wang Y D, Jin J, et al. Analysis on Regional Innovation System Mode and Its Evolution —_From the Perspective of Exploitation-exploration[J]. R \& D Management, 2015.

[4]Perlman D. Change in affect and needs satisfaction for amotivated students within the sport education model.[J]. Journal of Teaching in Physical Education, 2010, 29(4):433-445.

[5]Webster C A, Caputi P, Perreault M, et al. Elementary Classroom Teachers' Adoption of Physical Activity Promotion in the Context of a Statewide Policy: An Innovation Diffusion and Socio-Ecologic Perspective.[J]. Journal of Teaching in Physical Education, 2013, 32(4):419-440.

[6]Trani E P. National Innovation and the Academic Research Enterprise: Public Policy in Global Perspective (review)[J]. Journal of Higher Education, 2011, 82(4):504-506.

[7]López S F, Astray B P, Pazos D R, et al. Are firms interested in collaborating with universities? An open-innovation perspective in countries of the South West European Space[J]. Service Business, 2015, 9(4):637-662.

[8]Zhang W P, Department P. On Construction Path of Double-professional Teachers in Higher Vocational Colleges from Perspective of Coordination Innovation[J]. Journal of Higher Education, 2014, 316(7133):736-741. 